\title{
BLOOD GLUCOSE VARIABILITY DURING THE FIRST 24 HOURS AND PROGNOSIS IN ACUTE STROKE PATIENTS TREATED WITH IV THROMBOLYSIS
}

\author{
Mehmet Yasir PEKTEZEL, Ezgi YILMAZ, Ethem Murat ARSAVA, Mehmet Akif TOPÇUOĞLU \\ Hacettepe University Faculty of Medicine, Department of Neurology, Ankara, TURKEY
}

\begin{abstract}
INTRODUCTION: Hyperglycemia in acute ischemic stroke decreases the effectiveness of intravenous tissue plasminogen activator (IV tPA) and increases its hemorrhagic complications. Therefore, optimization of blood glucose (BG) is suggested. But, no consensus is achieved on which of the BG parameters to be used such as admission BG, post-treatment BG, first day maximum and average $B G$ (maxBG and aveBG), or BG variability indices such as the standard deviation of mean $B G$ (SDBG), coefficient of variation of BG (CVBG) and J-index.

METHODS: Admission and 24h BG were measured in 145 acute stroke patients (55\% female, age: $70 \pm 13$ yr; NIHSS: $14 \pm 6$, symptom-to-needle time: $160 \pm 58$ minutes) treated with IV tPA. BG variability indices were evaluated in 107 patients with serial BG measurement available.

RESULTS: AveBG was significantly higher in patients with 3rd month mRS>2 (46.2\%), but admission BG, SDBG, CVBG and $\mathrm{J}$-index were not significantly different. An exploratory regression analysis indicated that the connection of aveBG to worse prognosis $(\beta=-0.155, p=0.045)$ persisted after adjustment for admission NIHSS, age and DM history. No BG parameter predicted symptomatic tPA-associated type-II intracerebral hemorrhage (6.7\%), albeit these patients had marginally higher average BG levels $(p=0.045)$. Presence of diabetes, HbA1c, admission $B G$, average first day BG and variability indices had not modified the beneficial (52\%) and dramatic response (28\%) to IV tPA.

DISCUSSION and CONCLUSION: Sustained hyperglycemia, not glucose variability, during the first 24 hour predicts poor prognosis in acute stroke patients treated with IV thrombolysis.

Keywords: Stroke, glucose, sugar, glycemia, tPA, thrombolysis, thrombolytic, efficacy.

\section{AKUT İSKEMIK İNMEDE İLK GÜN İÇINNDEKI KAN ŞEKERİ DEĞIŞKENLİĞI VE İNTRAVENÖZ DOKU PLAZMINOJEN AKTIVATÖRÜNE YANIT}

\section{ÖZET}

GİRIŞ ve AMAÇ: Akut iskemik inmede hiperglisemi, intravenöz doku plazminojen aktivatörünün (IV tPA) etkinliğini azaltıp, hemorajik komplikasyonlarını arttırabilir. Bu nedenle, IV tPA uygulanan olgularda kan şekeri (KŞ) optimizasyonu temel öneriler arasındadır. Ancak, bu amaçla KȘ ve değişkenliğini gösteren giriş KȘ, tedavi sonrası KȘ, ilk gün maksimum ve ortalama KŞ (maksKŞ ve ortKŞ), ortalama KȘ standart sapması (KȘSD), KŞ varyasyon katsayısı (KȘCV) ve J-endeksi gibi parametrelerin hangisinin kullanımının en uygun olduğu açısından görüş birliği yoktur.

YÖNTEM ve GEREÇLER: IV tPA ile tedavi edilen 145 akut inme hastasında (\% 55 kadın, yaș: $70 \pm 13$ yll; NIHSS: $14 \pm 6$, semptom-iğne zamanı: $160 \pm 58$ dakika) tedavi öncesi ve 24. saat KŞ ölçüldü. KŞ değişkenlik göstergeleri ise seri KŞ ölçümü yapılabilen 107 olguda incelendi.

BULGULAR: Üçüncü ay modifiye Rankin skoru (mRS) > 2 olanlarda $(\% 46,2)$ IV tPA uygulamasının ilk günü ortalama KȘ anlamlı olarak yüksek iken, giriş KŞ, KŞSD, KŞCV ve J-endeksinde farklılık gözlenmedi. Regresyon analizi modellemesi ortalama KŞ yüksekliği ile kötü prognoz bağlantısının kabul NIHSS, yaş ve DM öyküsü ile uyarlandıktan sonra da devam ettiğini göstermiștir $(\beta=-0,155, p=0,045)$. OrtKŞ, tPA ilişkili tip-II intraserebral kanama hastalarında $(\% 6,7)$ daha yüksek olsa da $(\mathrm{p}=0,045)$, KŞ parametreleri bu modellerde genel olarak semptomatik kanama riskinin öngörülebilmesi

Corresponding author: Mehmet Akif Topcuoglu, Prof. MD. Hacettepe University, Faculty of Medicine, Department of Neurology, 06100 Sihhiye, Ankara, Turkey.

Telephone: +903123051806 E-mail: matopcuoglu@yahoo.com

Received: 30.01.2019 Accepted: 04.03.2019

This article should be cited as following: Pektezel M.Y, Yılmaz E, Arsava E.M, Topçuoglu MA. Blood glucose variability during the first 24 hours and prognosis in acute stroke patients treated with IV thrombolysis. Turkish Journal of Cerebrovascular Diseases 2019; 25 (1): 19-25. doi: $10.5505 /$ tbdhd.2019.02486 
kapsamında bağımsız gösterge belirmemiștir. Diyabet varlığı, HbA1c, giriș KŞ, ortKŞ ve KŞ değișkenlik indisleri IV tPA'dan yararlanma (\% 52) ve dramatik yanıt verme (\% 28) olasılığını anlamlı olarak etkilememiştir.

TARTIŞMA ve SONUÇ: : IV tromboliz ile tedavi edilen akut inmeli hastalarda kötü prognozun öngörülmesi bağlamında 24 saat boyunca sürekli hiperglisemi olması du dönemdeki kan şekeri değişkenliğinden daha önemli bir belirteçtir.

Anahtar Sözcükler: İnme, glukoz, şeker, glisemi, tPA, tromboliz, trombolitik, yarar.

\section{INTRODUCTION}

Diabetes is a significant interchangeable risk factor for all cardiovascular diseases, including stroke. $[1,2]$ In addition, the high blood glucose level (usually defined as $140 \mathrm{mg} / \mathrm{dL}$ ) following an acute ischemic vascular event is a significant factor that worsens the prognosis always $[3,4]$. Hyperglycemia increases the rate of complications after acute ischemic stroke, while adversely affecting the fate of ischemic tissue [5, 6]. In cases with acute ischemic stroke treated with intravenous (IV) recombinant tissue plasminogen activator (tPA), it was observed that high blood glucose levels before treatment and its remaining high after treatment decreased tPA response rate, i.e recanalization/reperfusion rate, in most of the studies and increased the risk of tPA complication, ie reperfusion bleeding [7-11]. In cases with high blood glucose levels, there is a high risk of inadequate clinical outcome and significant deficit (modified Rankinscale-mRS $>2$ ) in the third month with IV tPA, the mortality and post-treatment symptomatic intracerebral hemorrhage ( $\mathrm{sICH})[4$, 9-12]. These adverse effects are more significant as long as the start of medication with IV tPA delays and the blood glucose level reaches up to a certain level $[4,13]$.

On the other hand, it is not exactly known whether the blood glucose variability (Glycemic variability, GV) becomes more prominent in acute conditions, which is associated with the development of vascular complications in diabetes and is generally increased with the progression of the disease [14]. Glycemic variability expansion was shown to increase in-hospital mortality in critical medical diseases, especially in sepsis, and to increase both mortality and major cardiac complication rates in acute coronary syndromes [15-19].

Similarly, some studies showed the relation of increased blood glucose variability in early period in patients with diabetic acute stroke with early neurological worsening and increased risk of cardiovascular mortality with functional poor prognosis for the third month. [20-22] However, this relation was not set forth in all studies [23].
The effect of blood glucose variability on prognosis in diabetic and non-diabetic stroke patients who were administered with IV tPA in acute period was also discussed in various series, however, quite different results were published $[14,23]$. The aim of this study is to review these results and to determine the effect of blood glucose level and its variability on thrombolytic response in a more homogenous acute stroke group who were treated with IV tPA.

\section{MATERIAL AND METHODS}

Patients: 145 consecutive patients with acute ischemic stroke who received intravenous tPA treatment for the past 9 years and whose blood glucose levels could be achieved on the first day were included in this retrospective analysis. The clinical and imaging data were extracted from our prospectively collected corporate stroke database; transthoracic echocardiography, 24-hour Holter, diffusion-weighted magnetic resonance imaging, and at least one craniocervical angiography, all constitute the minimum level of protocol that this prospective database was based upon.

The national standard IV tPA administration protocol and metrics were complied with to the maximum extent in all patients. The study protocol and the database were approved by the local ethics committee. Patients with acute stroke who were treated by interventional techniques such as thrombectomy were excluded from the study.

The clinical stroke weight was assessed before IV tPA, 24 hours after IV tPA and at discharge by National Institutes of Health Stroke Scale (NIHSS) [24]. Functional outcome at the end of third month was assessed by modified Rankin score (mRS) as the main criterion for stroke prognosis [25]. "Favorable response" to IV tPA was defined as reduction of NIHSS more than 4 points after administration or its drop to 0 or 1 point at the end of 24 hours following IV tPA. When the reduction of NIHSS is 8 points or greater, it was classified as "dramatically favorable response" to IV tPA [26]. The prognosis was defined as "good" when mRS is 2 or lesser $(0,1,2)$, and as "excellent" 
when it is 0 or 1 . The Causative Classification of Stroke algorithm was used for "Stroke Etiologic Classification" [27].

Blood glucose variables: Electronic and written files were reviewed in a way to reflect the retrospective nature of the study, and both fingertip blood and bedtime blood glucose values were noted. Blood glucose level above $140 \mathrm{mg} / \mathrm{dL}$ was considered as hyperglycemia. Hemoglobin $\mathrm{A} 1 \mathrm{c}>7 \%$ in the hyperglycemic patients with no previous diabetes diagnosis was considered as new-diagnosis diabetes. The glucose level was checked 2,6 $\pm 1,6$ times in patients with positive diabetes history, and 2,1 \pm 1 times in patients with no positive diabetes history.

The blood glucose levels studied: The blood glucose first measured in the emergency department (pre-treatment BG); blood glucose at the 24th hour (24th hour BG); First day average blood glucose (24-hour average BG); Standard deviation of average blood sugar on the first day (24-hour BG SD), 24 hour blood glucose variation coefficient (Formula: "SD/average"; 24-hour BG $\mathrm{CV}$ ) and J index (Formula: (average blood glucose +SD) 2", mg/dL, J-index) [28]

Statistics: All values were given as "average + standard deviation [SD]", 95\% confidence interval [95\% CI] "percentage" or "median", according to the situation. The distribution normality was assessed by Kolmogorov-Simirnov and ShapiroWilks tests. Mann-Whitney U/ Student-t, "paired-t" and Chi-square / "exact" tests were used where necessary to determine the differences between the groups. Multivariate models were established to determine the effect of blood glucose parameters on tPA, tPA-related "symptomatic intra-parenchymal hemorrhage", efficacy of IV tPA and its effect on 3-month positive outcomes. The variables that provided " 0,1 " $p$ value in the first stage of the models were accepted to the final analysis. The level of statistical significance was set at $\mathrm{p}<0.05$. SPSS version 22 was used for all calculations.

\section{RESULTS}

It was found that $52 \%$ of 145 cases included in the study (55\% women, age: $70 \pm 13$ years, NIHSS: $14 \pm 6$; onset-to-tPA administration interval: $160 \pm 58$ minutes) responded positively and $28 \%$ thereof responded dramatically to IV tPA. No significant difference was found in the blood glucose at the time of arrival and average blood glucose as well as glucose variability parameters for these patients who positively responded to tPA and for whom a better prognosis, less hospitalization duration and less hemorrhagic complication were observed. However, HbA1c and average blood glucose in the first 24 hours were numerically high in the patients with poor IV tPA response (Table I).

At the end of third month, the rate of good clinical outcome (mRS 0-2) was found as $46,2 \%$ and excellent outcome (mRS $0-1$ ) was 33\%. The duration of hospitalization, symptomatic intracerebral hemorrhage and main artery occlusion were lower in these patients, as expected. Age, pre-treatment NIHSS and hypertension adversely affect, that's decrease, the positive functional outcome in both categories. On the first day, the average blood glucose was significantly higher in patients who did not have a good functional outcome $(21 \mathrm{mg} / \mathrm{dL}$ more averagely, $\mathrm{p}=0.008$ for mRS $0-1 ; \mathrm{p}=0.005$ for $\mathrm{mRS}$ $0-2$, see Table-2).The effect of glycemic variability on prognosis was neutral (Table II).

The independence of the finding that the first day average blood glucose is a predictor of poor prognosis was examined in various linear regression models and found significant in all of them. For example, in the model extrapolated with the presence of hypertension, the presence of diabetes, NIHSS, age (decade), only the blood glucose average was found to be an independent predictor of poor prognosis $(\beta=-0,155, p=0,045)$ in addition to NIHSS $(\beta=-0,393, p<0,001)$.

The incidence rate of any type of hemorrhagic transformation was $27.6 \%$ and was associated with the formation of atrial fibrillation only. No difference was observed in terms of glycemia values and variability indexes. In 10 (6.7\%) patients with symptomatic intracerebral hemorrhage, the average blood glucose level was $28 \mathrm{mg} / \mathrm{dL}$ higher in the first 24 hours $(\mathrm{p}=0.045$, see Table III).

\section{DISCUSSION}

The high blood glucose level in first 24 hours following the treatment in patients with acute ischemic stroke who were administered with IV tPA adversely affects the third month functional outcome. Out study confirmed multiple studies which reveal and support this idea in the literature [29-31].In the light of this information, it is recommended to keep blood glucose in 140-180 
Pektezel et al.

Table I. Clinical response to IV tPA.

\begin{tabular}{|c|c|c|c|c|c|c|}
\hline & \multicolumn{2}{|c|}{ Good response } & \multicolumn{4}{|c|}{ Dramatic response } \\
\hline & Yes $(\mathrm{n}=76)$ & No $(n=69)$ & $P$ & Yes $(n=41)$ & No $(n=104)$ & $P$ \\
\hline Age & $69 \pm 13$ & $70 \pm 13$ & 0,672 & $70 \pm 15$ & $69 \pm 13$ & 0,920 \\
\hline Gender, female & $55 \%$ & $55 \%$ & 0,982 & $61 \%$ & $53 \%$ & 0,378 \\
\hline VKI & $27,9 \pm 6,1$ & $27,5 \pm 5,1$ & 0,742 & $28,6 \pm 7,1$ & $27,3 \pm 4,8$ & 0,281 \\
\hline Hypertension & $65 \%$ & $73 \%$ & 0,302 & $56 \%$ & $73 \%$ & 0,048 \\
\hline Diabetes & $20 \%$ & $29 \%$ & 0,228 & $20 \%$ & $27 \%$ & 0,352 \\
\hline Atrial fibrillation & $29 \%$ & $38 \%$ & 0,264 & $29 \%$ & $35 \%$ & 0,538 \\
\hline Cardioembolism & $58 \%$ & $59 \%$ & 0.924 & $55 \%$ & $60 \%$ & 0,632 \\
\hline Symptom-to-door duration (min) & $77 \pm 40$ & $82 \pm 46$ & 0,691 & $91 \pm 49$ & $76 \pm 39$ & 0,058 \\
\hline NIHSS arrival & $13,6 \pm 5,5$ & $14,7 \pm 5,9$ & 0,239 & $13,2 \pm 5,9$ & $14,5 \pm 5,6$ & 0,219 \\
\hline Symptom-to-needle duration (min) & $150 \pm 54$ & $171 \pm 61$ & 0,030 & $164 \pm 67$ & $159 \pm 54$ & 0,626 \\
\hline Hospitalization duration & $16 \pm 25$ & $27 \pm 28$ & 0,016 & $12 \pm 19$ & $25 \pm 28$ & 0,004 \\
\hline Any hemorrhage & $18 \%$ & $37 \%$ & 0,010 & $10 \%$ & $35 \%$ & 0,003 \\
\hline PH2 & $1 \%$ & $13 \%$ & 0,005 & $0 \%$ & $10 \%$ & 0,040 \\
\hline M1 / TICA / BA occlusion & $43 \%$ & $55 \%$ & 0,161 & $42 \%$ & $52 \%$ & 0.257 \\
\hline No occlusion & $21 \%$ & $12 \%$ & 0.126 & $29 \%$ & $12 \%$ & 0,010 \\
\hline \multicolumn{7}{|l|}{ Parameters of glycemia } \\
\hline HbA1c & $6,14 \pm 1,05$ & $6,48 \pm 1,32$ & 0,215 & $5,91 \pm 0,91$ & $6,45 \pm 1,25$ & 0,057 \\
\hline Pre-treatment BG & $140 \pm 57$ & $147 \pm 54$ & 0,497 & $139 \pm 47$ & $145 \pm 58$ & 0,600 \\
\hline 24-hour average BG & $132 \pm 45$ & $138 \pm 44$ & 0,451 & $125 \pm 36$ & $139 \pm 47$ & 0,067 \\
\hline 24-hour BG SD & $20,52 \pm 26,28$ & $21,97 \pm 24,84$ & 0,742 & $20,71 \pm 29,98$ & $21,41 \pm 23,73$ & 0,887 \\
\hline 24-hour BG CV & $0,18 \pm 0,16$ & $0,18 \pm 0,14$ & 0,892 & $0,2 \pm 0,18$ & $0,17 \pm 0,14$ & 0,326 \\
\hline J-index & $29,25 \pm 26,4$ & $28,39 \pm 18,28$ & 0,843 & $30,14 \pm 25,32$ & $28,43 \pm 22,02$ & 0,735 \\
\hline
\end{tabular}

Abbreviations; BA: Basilar artery; CV: Coefficient of Variation; Min: Minute; HbA1c:Hemoglobin A1c; ICA:internal carotid artery; IV: Intravenous; BG: Blood Glucose; M1: middle cerebral artery (MCA) first segment; NIHSS: National Institute of Health Stroke Scale; PH2:Parenchymal hematoma type-2; SD:Standard deviation; tPA: tissue plasminogen activator; BMI: Body Mass Index.

Table II. Clinical outcomes with IV tPA.

\begin{tabular}{|c|c|c|c|c|c|c|}
\hline & \multicolumn{2}{|c|}{ Perfect outcome [mRS $\leq 1]$} & \multicolumn{4}{|c|}{ Good outcome [mRS $\leq 2]$} \\
\hline & Yes $(n=48)$ & No $(n=96)$ & $P$ & Yes $(\mathrm{n}=67)$ & No $(n=78)$ & $P$ \\
\hline Age & $65 \pm 14$ & $72 \pm 12$ & 0,004 & $66 \pm 14$ & $72 \pm 12$ & 0,004 \\
\hline Gender, female & $58 \%$ & $53 \%$ & 0,554 & $52 \%$ & $52 \%$ & 0,555 \\
\hline BMI & $27,4 \pm 5,1$ & $27,9 \pm 5,9$ & 0,658 & $29,0 \pm 6,9$ & $26,7 \pm 4,2$ & 0,050 \\
\hline Hypertension & $50 \%$ & $77 \%$ & 0.001 & $58 \%$ & $77 \%$ & 0,018 \\
\hline Diabetes & $21 \%$ & $27 \%$ & 0,414 & $24 \%$ & $36 \%$ & 0.772 \\
\hline Atrial fibrillation & $31 \%$ & $34 \%$ & 0,708 & $27 \%$ & $39 \%$ & 0.125 \\
\hline Cardioembolism & $55 \%$ & $61 \%$ & 0.488 & $55 \%$ & $63 \%$ & 0.394 \\
\hline Symptom-to-door duration (min) & $83 \pm 44$ & $79 \pm 43$ & 0,568 & $84 \pm 48$ & $77 \pm 38$ & 0,334 \\
\hline NIHSS arrival & $11,8 \pm 5,7$ & $15,3 \pm 5,4$ & $<0,001$ & $11,6 \pm 5,3$ & $16,4 \pm 5,1$ & $<0,001$ \\
\hline Symptom-to-needle duration (min) & $158 \pm 62$ & $162 \pm 57$ & 0,670 & $160 \pm 62$ & $161 \pm 55$ & 0,845 \\
\hline Hospitalization duration & $10 \pm 6$ & $26 \pm 31$ & 0,001 & $11 \pm 6$ & $30 \pm 33$ & $<0,001$ \\
\hline Any hemorrhage & $15 \%$ & $34 \%$ & 0,112 & $18 \%$ & $36 \%$ & 0,016 \\
\hline PH2 & $0 \%$ & $10 \%$ & 0,020 & $0 \%$ & $13 \%$ & 0,002 \\
\hline M1 / TICA / BA occlusion & $40 \%$ & $53 \%$ & 0.125 & $39 \%$ & $57 \%$ & 0.028 \\
\hline No occlusion & $23 \%$ & $14 \%$ & 0,155 & $20 \%$ & $14 \%$ & 0,411 \\
\hline \multicolumn{7}{|l|}{ Parameters of glycemia } \\
\hline HbA1c & $6 \pm 0,84$ & $6,44 \pm 1,32$ & 0,119 & $6,13 \pm 0,92$ & $6,44 \pm 1,4$ & 0,268 \\
\hline Pre-treatment BG & $132 \pm 44$ & $148 \pm 60$ & 0,153 & $135 \pm 45$ & $151 \pm 63$ & 0,131 \\
\hline 24-hour average BG & $121 \pm 34$ & $142 \pm 48$ & 0,008 & $124 \pm 34$ & $145 \pm 51$ & 0,005 \\
\hline 24-hour BG SD & $20,8 \pm 29,42$ & $21,59 \pm 23,65$ & 0,573 & $20,84 \pm 26,49$ & $21,79 \pm 24,91$ & 0,830 \\
\hline 24-hour BG CV & $0,19 \pm 0,18$ & $0,17 \pm 0,14$ & 0,509 & $0,18 \pm 0,16$ & $0,18 \pm 0,15$ & 0,817 \\
\hline J-index & $26,25 \pm 23,4$ & $30,25 \pm 22,56$ & 0,393 & $25,82 \pm 21,12$ & $31,99 \pm 24,09$ & 0,155 \\
\hline
\end{tabular}

Abbreviations; BA: Basilar artery; CV: Coefficient of Variation; Min:Minute; HbA1c: Hemoglobin A1c; ICA: internal carotid artery; IV: Intravenous; BG: Blood Glucose; M1: middle cerebral artery (MCA) first segment; NIHSS: "National Institute of Health Stroke Scale"; PH2: Parenchymal hematoma type-2; SD: Standard deviation; tPA: tissue plasminogen activator; BMI: Body Mass Index. 
Table III. Post IV tPA hemorrhage.

\begin{tabular}{|c|c|c|c|c|c|c|}
\hline & \multicolumn{2}{|c|}{ Hemorrhage } & \multicolumn{4}{|c|}{ PH type 2} \\
\hline & Yes $(n=40)$ & No $(n=105)$ & $P$ & Yes $(n=10)$ & No $(n=135)$ & $P$ \\
\hline Age & $69 \pm 12$ & $70 \pm 14$ & 0,950 & $69 \pm 14$ & $70 \pm 13$ & 0,845 \\
\hline Gender, female & $63 \%$ & $53 \%$ & 0,294 & $50 \%$ & $56 \%$ & 0,718 \\
\hline BMI & $27,1 \pm 4,6$ & $27,9 \pm 5,9$ & 0,580 & $25,5 \pm 4,1$ & $27,9 \pm 5,7$ & 0,284 \\
\hline Hypertension & $73 \%$ & $67 \%$ & 0,522 & $60 \%$ & $69 \%$ & 0,549 \\
\hline Diabetes & $28 \%$ & $24 \%$ & 0,624 & $20 \%$ & $25 \%$ & 0,723 \\
\hline Atrial fibrillation & $48 \%$ & $27 \%$ & 0,021 & $30 \%$ & $33 \%$ & 0,841 \\
\hline Cardioembolism & $63 \%$ & $56 \%$ & 0,477 & $50 \%$ & $59 \%$ & 0,614 \\
\hline Symptom-to-door duration (min) & $70 \pm 37$ & $85 \pm 45$ & 0,056 & $64 \pm 39$ & $82 \pm 44$ & 0,194 \\
\hline NIHSS arrival & $15,6 \pm 4,7$ & $13,5 \pm 6$ & 0,046 & $16,6 \pm 4,2$ & $13,4 \pm 5,8$ & 0,143 \\
\hline Symptom-to-needle duration (min) & $157 \pm 49$ & $161 \pm 61$ & 0,743 & $152 \pm 46$ & $161 \pm 59$ & 0,631 \\
\hline Hospitalization duration & $24 \pm 26$ & $20 \pm 27$ & 0,367 & $35 \pm 48$ & $20 \pm 24$ & 0,092 \\
\hline M1 / TICA / BA occlusion & $58 \%$ & $45 \%$ & 0,188 & $60 \%$ & $48 \%$ & 0,456 \\
\hline No occlusion & $8 \%$ & $20 \%$ & 0,073 & $10 \%$ & $17 \%$ & 0,569 \\
\hline \multicolumn{7}{|l|}{ Parameters of glycemia } \\
\hline HbA1c & $6,48 \pm 0,85$ & $6,22 \pm 1,24$ & 0,433 & $6,33 \pm 0,74$ & $6,27 \pm 1,19$ & 0,923 \\
\hline Pre-treatment BG & $135 \pm 35$ & $146 \pm 60$ & 0,347 & $153 \pm 38$ & $143 \pm 56$ & 0,651 \\
\hline 24-hour average BG & $140 \pm 31$ & $133 \pm 49$ & 0,342 & $161 \pm 37$ & $133 \pm 45$ & 0,045 \\
\hline 24-hour BG SD & $19,51 \pm 23,76$ & $21,9 \pm 26,11$ & 0,628 & $24 \pm 25,03$ & $21,04 \pm 25,54$ & 0,726 \\
\hline 24-hour BG CV & $0,16 \pm 0,14$ & $0,18 \pm 0,16$ & 0,578 & $0,2 \pm 0,16$ & $0,18 \pm 0,15$ & 0,741 \\
\hline J-index & $28,98 \pm 17,14$ & $28,72 \pm 24,44$ & 0,958 & $38,08 \pm 14,54$ & $28,08 \pm 23,05$ & 0,230 \\
\hline
\end{tabular}

Abbreviations; BA: Basilar artery; CV: Coefficient of Variation; Min: Minute; HbA1c: Hemoglobin A1c; ICA: internal carotid artery; IV: Intravenous; BG: Blood Glucose; M1: middle cerebral artery (MCA) first segment; NIHSS: "National Institute of Health Stroke Scale";PH2: Parenchymal hematoma type-2; SD: Standard deviation; tPA: tissue plasminogen activator; BMI: Body Mass Index.

$\mathrm{mg} / \mathrm{dL}$ band within the first 24 hours in the guidelines for acute ischemic treatment [32].This is considered as a quality metric.

High blood glucose level is a common incident in the hyperacute period following an ischemic stroke and is considered to be an indicator of acute stress response. Hyperglycemic patients also benefit from IV tPA; however, high level of glucose reduces the effectiveness of thrombolytic therapy [4, 29-31]. In case of high blood glucose, the re-canalization creating and/or enhancing effect of tPA decreases, and a resistance is developed against thrombolytic agent. The first coming the mind out of the factors playing a role here is the the fact that the level of plasminogen activator inhibitor-type 1 (PAI-1) increases due to high blood glucose and hyperinsulism in diabetes and antagonizes tPA. In other words, fibrinolysis decreases in hyperglycemia [33]. Besides, the hyperglycemia directly increasing the coagulation and decreasing penumbral vasodilatation reduces the success of reperfusion. [23] When recanalization and reperfusion are ensured, high blood glucose level and/or its remaining at high levels increases the reperfusion damage and facilitates the development of hemorrhagic complications. Hyperglycemia-induced or increased oxidative stress, lactate accumulation, and tissue acidosis, increased matrix metalloproteinase level may be mediating this effect [23, 34]. On the basis of all these physiopathological logical explanations, we can mention that large scaled studies are required on determination of post-stroke blood glucose target values in hyperacute period, specific to the patients who were administered with IV tPA.

It was observed in our study that the basic glycemic variability parameters and their response to IV tPA are not related. This is not a subject studied in detail in the literature [14, 23]. It was addressed in a study, similar to our finding, that the average blood glucose level is important for the response to IV tPA, however BGSD is not a significant determinant as a GV indicator [35]. In another study, it was reported that J-index values are important in increasing cardiovascular mortality in these patients [20]. Glycemic variability is known to have an effect in a way to increase the vascular complications of diabetes in long term over various mechanisms, particularly oxidative stress $[14,17,23,28,36]$. Poor microand macrovascular status has the potential to adversely affect the prognosis of acute stroke. On the other hand, in at least three retrospective studies, the positive association between GV and increased mortality in ICU patients were shown to be more prominent in non-diabetic patients $[15$, 37-39]. In addition, a similar association was also observed in cases with traumatic brain injury [40]. Therefore, the same situation could be expected in 
acute stroke cases who were administered with IV tPA, however, this was not supported by initial data. Preferably prospective and large-scale studies in more diverse designs should be planned to elucidate this problem.

Considering the evaluation of our results, it is necessary to address some limitations of our study. First of all, this is a retrospective analysis; a single-center data and the number of patients is "median" for such studies. In addition, the recanalization could not be documented for each patient. Moreover, as "post-stroke" hyperglycemia shows a positive correlation with acute stress response and more importantly with the cerebral infarction size, it was claimed that there is a epiphenomen in terms of prognosis [41]. However, we did not receive neuroimagings for consideration. Most importantly, the number of blood glucose measurements in our study was low and limited to 2-4 measurements in most of the patients. By the increase of this number and periodical checks in certain intervals, basic GV parameters, particularly BG standard deviation, could be more important. Lastly, the nutrition, fluid infusion and insulin administration for the patients were not recorded. Despite all these limitations, our study showed that the high level of blood glucose, rather than variability thereof, has a role on the efficacy of IV tPA. It would be efficient to test this data on a large scale.

\section{REFERENCES}

1. Kruyt ND, Biessels GJ, Devries JH, Roos YB. Hyperglycemia in acute ischemic stroke: pathophysiology and clinical management. Nat Rev Neurol. 2010;6:145-55.

2. Melamed E. Reactive hyperglycaemia in patients with acute stroke. J Neurol Sci. 1976;29:267-75.

3. Kim EJ, Jeong MH, Kim JH, Ahn TH, Seung KB, Oh DJ, et al. Clinical impact of admission hyperglycemia on in-hospital mortality in acute myocardial infarction patients. Int J Cardiol. 2017;236:9-15.

4. Ahmed N, Davalos A, Eriksson N, Ford GA, Glahn J, Hennerici M, et al. Association of admission blood glucose and outcome in patients treated with intravenous thrombolysis: results from the Safe Implementation of Treatments in Stroke International Stroke Thrombolysis Register (SITS-ISTR). Arch Neurol. 2010;67:1123-30.

5. Roh JK, Hong SB, Yoon BW, Kim MS, Myung H. The effect of hyperglycemia on lipid peroxidation in the global cerebral ischemia of the rat. J Korean Med Sci. 1992;7:40-6.

6. Fuentes B, Castillo J, San Jose B, Leira R, Serena J, Vivancos $\mathrm{J}$, et al. The prognostic value of capillary glucose levels in acute stroke: the GLycemia in Acute Stroke (GLIAS) study. Stroke. 2009;40:562-8.

7. Idicula TT, Waje-Andreassen U, Brogger J, Naess $H$, Lundstadsveen MT, Thomassen L. The effect of physiologic derangement in patients with stroke treated with thrombolysis. J Stroke Cerebrovasc Dis. 2008;17:141-6.
8. Saqqur M, Shuaib A, Alexandrov AV, Sebastian J, Khan K, Uchino K. The correlation between admission blood glucose and intravenous rt-PA-induced arterial recanalization in acute ischemic stroke: a multi-centre TCD study. Int J Stroke. 2015;10:1087-92.

9. Masrur S, Cox M, Bhatt DL, Smith EE, Ellrodt G, Fonarow GC, et al. Association of Acute and Chronic Hyperglycemia With Acute Ischemic Stroke Outcomes Post-Thrombolysis: Findings From Get With The Guidelines-Stroke. J Am Heart Assoc. 2015;4:e002193.

10. Putaala J, Sairanen T, Meretoja A, Lindsberg PJ, Tiainen M, Liebkind R, et al. Post-thrombolytic hyperglycemia and 3month outcome in acute ischemic stroke. Cerebrovasc Dis. 2011;31:83-92.

11. Poppe AY, Majumdar SR, Jeerakathil T, Ghali W, Buchan AM, Hill MD, et al. Admission hyperglycemia predicts a worse outcome in stroke patients treated with intravenous thrombolysis. Diabetes Care. 2009;32:617-22.

12. Lin SF, Chao AC, $\mathrm{Hu} \mathrm{HH}$, Lin RT, Chen $\mathrm{CH}$, Chan L, et al. Hyperglycemia predicts unfavorable outcomes in acute ischemic stroke patients treated with intravenous thrombolysis among a Chinese population: A prospective cohort study. J Neurol Sci. 2018;388:195-202.

13. Rosso C, Baronnet F, Diaz B, Le Bouc R, Frasca Polara G, Moulton EJ, et al. The silver effect of admission glucose level on excellent outcome in thrombolysed stroke patients. J Neurol. 2018;265:1684-9.

14. Monnier L, Mas E, Ginet C, Michel F, Villon L, Cristol JP, et al. Activation of oxidative stress by acute glucose fluctuations compared with sustained chronic hyperglycemia in patients with type 2 diabetes. JAMA. 2006;295:1681-7.

15. Egi M, Bellomo R, Stachowski E, French CJ, Hart G. Variability of blood glucose concentration and short-term mortality in critically ill patients. Anesthesiology. 2006;105:244-52.

16. Ali NA, O'Brien JM, Jr., Dungan K, Phillips G, Marsh CB, Lemeshow $\mathrm{S}$, et al. Glucose variability and mortality in patients with sepsis. Crit Care Med. 2008;36:2316-21.

17. Ceriello A, Ihnat MA. 'Glycaemic variability': a new therapeutic challenge in diabetes and the critical care setting. Diabet Med. 2010;27:862-7.

18. Lipska KJ, Venkitachalam L, Gosch K, Kovatchev B, Van den Berghe G, Meyfroidt G, et al. Glucose variability and mortality in patients hospitalized with acute myocardial infarction. Circ Cardiovasc Qual Outcomes. 2012;5:550-7.

19. Takahashi $\mathrm{H}$, Iwahashi $\mathrm{N}$, Kirigaya J, Kataoka $\mathrm{S}$, Minamimoto $Y$, Gohbara $M$, et al. Glycemic variability determined with a continuous glucose monitoring system can predict prognosis after acute coronary syndrome. Cardiovasc Diabetol. 2018;17:116.

20. Yoon JE, Sunwoo JS, Kim JS, Roh H, Ahn MY, Woo HY, et al. Poststroke glycemic variability increased recurrent cardiovascular events in diabetic patients. J Diabetes Complications. 2017;31:390-4.

21. Hui J, Zhang J, Mao X, Li Z, Li X, Wang F, et al. The initial glycemic variability is associated with early neurological deterioration in diabetic patients with acute ischemic stroke. Neurol Sci. 2018;39:1571-7.

22. Kim YS, Kim C, Jung KH, Kwon HM, Heo SH, Kim BJ, et al. Range of glucose as a glycemic variability and 3-month outcome in diabetic patients with acute ischemic stroke. PLoS One. 2017;12:e0183894.

23. Gonzalez-Moreno EI, Camara-Lemarroy CR, GonzalezGonzalez JG, Gongora-Rivera F. Glycemic variability and acute ischemic stroke: the missing link? Transl Stroke Res. 2014;5:638-46. 
24. Brott T, Adams HP, Jr., Olinger CP, Marler JR, Barsan WG, Biller J, et al. Measurements of acute cerebral infarction: a clinical examination scale. Stroke. 1989;20:864-70.

25. Bonita R, Beaglehole R. Recovery of motor function after stroke. Stroke. 1988;19:1497-500.

26. Topcuoglu MA, Arsava EM, Kursun O, Akpinar E, Erbil B. The utility of middle cerebral artery clot density and burden assessment by noncontrast computed tomography in acute ischemic stroke patients treated with thrombolysis. J Stroke Cerebrovasc Dis. 2014;23:e85-91.

27. Ay H, Furie KL, Singhal A, Smith WS, Sorensen AG, Koroshetz WJ. An evidence-based causative classification system for acute ischemic stroke. Ann Neurol. 2005;58:688-97.

28. Service FJ. Glucose variability. Diabetes. 2013;62:1398-404.

29. Bruno A, Levine SR, Frankel MR, Brott TG, Lin Y, Tilley BC, et al. Admission glucose level and clinical outcomes in the NINDS rt-PA Stroke Trial. Neurology. 2002;59:669-74.

30. Alvarez-Sabin J, Molina CA, Ribo M, Arenillas JF, Montaner J, Huertas R, et al. Impact of admission hyperglycemia on stroke outcome after thrombolysis: risk stratification in relation to time to reperfusion. Stroke. 2004;35:2493-8.

31. Leigh R, Zaidat O0, Suri MF, Lynch G, Sundararajan S, Sunshine JL, et al. Predictors of hyperacute clinical worsening in ischemic stroke patients receiving thrombolytic therapy. Stroke. 2004;35:1903-7.

32. Powers WJ, Rabinstein AA, Ackerson T, Adeoye OM, Bambakidis NC, Becker K, et al. 2018 Guidelines for the Early Management of Patients With Acute Ischemic Stroke: A Guideline for Healthcare Professionals From the American Heart Association/American Stroke Association. Stroke. 2018;49:e46-e110.

33. Pandolfi A, Giaccari A, Cilli C, Alberta MM, Morviducci L, De Filippis EA, et al. Acute hyperglycemia and acute hyperinsulinemia decrease plasma fibrinolytic activity and increase plasminogen activator inhibitor type 1 in the rat. Acta Diabetol. 2001;38:71-6.
34. Els T, Klisch J, Orszagh M, Hetzel A, Schulte-Monting J, Schumacher M, et al. Hyperglycemia in patients with focal cerebral ischemia after intravenous thrombolysis: influence on clinical outcome and infarct size. Cerebrovasc Dis. 2002;13:89-94.

35. Yoo DS, Chang J, Kim JT, Choi MJ, Choi J, Choi KH, et al. Various blood glucose parameters that indicate hyperglycemia after intravenous thrombolysis in acute ischemic stroke could predict worse outcome. PLoS One. 2014;9:e94364.

36. Hirsch IB. Glycemic variability: it's not just about A1C anymore! Diabetes Technol Ther. 2005;7:780-3.

37. Dossett LA, Cao H, Mowery NT, Dortch MJ, Morris JM, Jr., May AK. Blood glucose variability is associated with mortality in the surgical intensive care unit. Am Surg. 2008;74:679-85; discussion 85.

38. Egi M, Bellomo R, Stachowski E, French CJ, Hart GK, Hegarty $\mathrm{C}$, et al. Blood glucose concentration and outcome of critical illness: the impact of diabetes. Crit Care Med. 2008;36:2249-55.

39. Krinsley JS. Glycemic variability: a strong independent predictor of mortality in critically ill patients. Crit Care Med. 2008;36:3008-13.

40. Matsushima K, Peng M, Velasco C, Schaefer E, Diaz-Arrastia $\mathrm{R}$, Frankel H. Glucose variability negatively impacts longterm functional outcome in patients with traumatic brain injury. J Crit Care. 2012;27:125-31.

41. Baird TA, Parsons MW, Phan T, Butcher KS, Desmond PM, Tress BM, et al. Persistent poststroke hyperglycemia is independently associated with infarct expansion and worse clinical outcome. Stroke. 2003;34:2208-14. 